\title{
Introduction to the Special Issue: Monumental Mistakes? Confronting Difficult Pasts
}

\author{
Cathryn van Kessel \\ Department of Secondary Education \\ University of Alberta \\ vankesse@ualberta.ca \\ David Scott \\ Werklund School of Education \\ University of Calgary \\ scottd@ucalgary.ca
}

It appears the past has never been so present as a widespread public concern. Over the summer, the Elementary Teachers' Federation of Ontario (2017), arguing that John A. Macdonald "perpetuated genocide against Indigenous people," called for the removal of Macdonald's name from schools across the province (para. 2). This summer also saw Indigenous activists in Halifax call for the removal of a statue memorializing Edward Cornwallis - a British officer who founded Halifax and offered a cash bounty to anyone who killed a Mi'kmaq person (Berman, 2017). The deeply contested nature of who and what from the past should be commemorated has not been limited to Canada. Vociferous debates continue to rage in the United States, most notably around commemorations of civil war figures (Vozzella, 2017).

Pointing to the intimate connection between public acts of remembrance and personal and collective identity, these controversies have struck a deep emotional chord. Politicians, columnists, and the general public have weighed into these debates staking out their position in public pronouncements, numerous op-ed columns, and on social media. Some have argued that as societal values change, so should what we as a political community choose to commemorate (Moscrop, 2017). Others have warned against erasing those in the in past that have been central to who and what 'we' are today (Paikin, 2017). There are no easy answers to questions raised in these debates. However, much is at stake in these discussions, not least of which are the ways young people and future generations come to imagine themselves together as a 'we' through the names that define public spaces.

This special issue of Canadian Social Studies, entitled Monumental Mistakes? Confronting Difficult Pasts, has brought together a diverse range of scholars offering insights into discussions regarding removing or altering monuments, buildings, and other reminders of difficult histories. We requested that contributors submit short essays that we hope will serve as accessible prompts for classroom and broader public conversations and inquiries. In an opening provocation, editor Kent den Heyer calls on educators to attend to the ways public memorials embody powerful emotionally laden fictions around Canada's official historical culture. Turning attentions away from a deficit reasoning around what knowledge students lack about the past, when engaging such debates, den 
Heyer calls on educators to consider the more future orientated question concerning what about what happened do we wish to honour and therefore become?

Adam Gaudry calls for Canadians to show their government how as a society we might amplify Indigenous voices to form a basis for more respectful relations on this land. With one crucial step involving diffusing the myths of John A. Macdonald, this truth-telling does not mean erasing Macdonald's role as a founder of Canada; rather, it attends to the ongoing colonization of Indigenous nations. But, what might we do with sites of Indigenous trauma like Indian Residential School buildings? In response to this complex question, Adriana Boffa highlights the need to attend to the multiplicity of opinions held by communities where these buildings are situated. Instead of the broader society seeking one "right" solution, the most helpful course of action for potential reconciliation, according to Boffa, will likely be different for each community. Some may need demolition for closure, while others might be empowered by repurposing or memorializing the physical structure.

Adding further insights around these themes, Lindsay Gibson uses the ethical dimension of historical thinking to critically examine calls to rename an elementary school in Regina named after Nicholas Davin who wrote an influential report advocating for residential schools. To this end, Gibson provides us with a series of questions that educators could work through with their students to determine whether this school should be renamed. Such a framing prevents us from glibly overgeneralizing intrinsically complex issues, and thus allows us to proceed in thoughtful and equitable ways. Adding further insight into how historical thinking can be used as a lens to examine such debates, Gabriel Reich's piece on continuity, change, and historical consciousness shifts our focus to the U.S. context. Reich specifically examines Richmond Virginia's Monument Avenue, Charlottesville, and the symbolic power of White supremacy. By connecting the past and the present, and examining monuments that can become taken-for-granted scenery, Reich offers new possibilities for thoughtfully engaging with troubled pasts.

The final three essays in this special issue call on us to reframe debates around public acts of historical remembrance to consider the oft-neglected aspects of colonial (re)production. In this regard, Bryan Smith examines banal, rather than highly publicized, examples of colonial topography. Through the example of the city now known as Toronto, Smith shows how critically examining city-texts can provide a generative way to thwart the insidiousness of the colonial settler project. In a subsequent essay, J-C Couture reminds us that it is vital to avoid conceptualizing "indigeneity" as a fixed entity. He engages with the example of the culturally-appropriated Inuksuk to interrogate how we approach Indigenous perspectives in the social studies curriculum. Along these lines, Couture reminds us that monuments (and curriculum) need not be reduced to one more piece of clutter, but, rather, reminders about where and how to be in the world. The final provocation in this special issue shifts our attention from specific instances of colonialism, to the monumental agent that is our educational institutions. Marc Higgins and Brooke Madden invite us to consider the colonial logics continually reified across both the materiality and spatiality of place. Providing a roadmap for this work, they offer 
three avenues for reorienting ourselves toward decolonization: producing, processing, and (re)presenting.

The thoughtful and scholarly pieces in this special issue provide social studies educators and researchers with new conceptual pathways to think about current debates about monuments that work to provoke, rather than shut down, thinking and sustained deliberation. Although engaging with the complexities of our colonial past and present is challenging academically and emotionally, the authors of essays in this issue provide a variety of ways we might re/think our situation. Critiquing the what is sometimes easy, but thinking about how we lodge and re/consider those critiques is a daunting task that challenges not only what we claim to know, but our very sense of who we might be, or what we might become.

\section{References}

Berman, P. (2017, October 4). Halifax council creates committee on Cornwallis, Indigenous history. $C B C$ News. Retrieved from http://www.cbc.ca/news/canada/nova-scotia/halifax-council-creates-committee-oncornwallis-indigenous-history-1.4321910

Elementary Teachers' Federation of Ontario (2017, August 24). ETFO passes motion to rename buildings named after Sir John A. Macdonald. ETFO/FEEO. Retrieved from http://bit.ly/2vt76kd

Moscrop, D. (2017, August 25). Rewriting history? That's how history is written in the first place. Maclean's Magazine. Retrieved from

http://www.macleans.ca/opinion/rewriting-history-thats-how-history-is-written-inthe-first-place/

Paikin, S. (2017). Historian 'mad as hell' about attacks on John A. Macdonald. TVO. Retrieved from https://tvo.org/blog/current-affairs/historian-mad-as-hell-aboutattacks-on-john-a-macdonald

Vozzella, L. (2017, June 22). Richmond mayor vows to confront tributes to southern civil war figures. The Washington Post. Retrieved from

https://www.washingtonpost.com/local/virginia-politics/in-the-former-capital-ofthe-confederacy-a-new-path-forward-on-monuments/2017/06/22/3133e044-56c3$\underline{11 \mathrm{e} 7-\mathrm{a} 204-\mathrm{ad} 706461 \mathrm{fa} 4 \mathrm{f} \text { story.html?utm term }=. \mathrm{d} 162 \mathrm{aa} 13 \mathrm{e} 9 \mathrm{fa}}$ 